\section{A CASE OF STRYCHNINE POISONING.}

By G. H. Сооке, M.R.C.S., L.R.C.P.,

LATE hOUSE PHYSICIAN, ROYAL INFIRMART, MANCIIESTER.

THE following case is given merely to show the caution which is necessary in some cases of poisoning. A. M-, male, aged fifty-two, was brought to the infirmary at 11.40 P. M. on August 17th, 1890, stated to have taken sorne poison about half an hour previously. When admitted he was quite rational, face slightly flushed, breath emitted an odour of alcohol, pupils dilated and reacted to light; tongue dry, rest of body fairly moist, limbs lax. Patient gave a history of drink, but denied taking any poison. The stomach was thoroughly washed out with the stomach pump, the fluid withdrawn emitting a strong odour of alcohol. It was afterwards found to contain strychnine by physiological and chemical tests. At 12 midnight, no other symptons being noticed, he was sent to the wards, and at 12.30 A.M. - -i.e., about one hour and a quarter after taking the poisonopisthotonos developed, the face muscles being unaffected. The pulse was 90 , fairly strong, respiration slightly irregular, skin moist, and tongue less dry. Strychnine was diagnosed, and he was given twenty grains each of chloral and potassium bromide; it did not afterwards become necessary to repeat it. The next morning be complained of feeling stiff, but he had sufficiently recovered to be able to leave the infirmary two days after. In the above case, without any history of poison, the cause might bave been overlooked and the patient discharged, for not until fully an hour after it had been taken did any definite symptoms appear, and with a vague history (no specimen of the poison was furnished until later) it is very difficult to separate true from pseudopoisoning cases. In any case it is advisable to wash out the stomach, a proceeding which will do no harm, and may be productive of a great amount of good.

Altrincham.

\section{d.}

oF

\section{HOSPITAL PRACTICE, BRITISH AND FOREIGN.}

Nulla autem est alia pro certo noscendi via, nisi quamplurimas et morborum et dissectionum historias, tum aliorum tum proprias collectas habere, et inter se comparare.-Morgagri De Sed. et Caus. Morb., ib. iv. Proœmium.

\section{PADDINGTON INFIRMARY.}

A CASE OF ELEPHANTIASIS TELANGIECTODES ; ${ }^{1}$ REMARKS.

(Under the care of Dr. THomis SATIL..)

THe short notes of this case which we have given illustrate a condition which, although described by Kaposi and Virchow, is not frequently met with in this country, and is interesting on that account. It is a peculiar form of fibrovascular hypertrophy, which, although probably of congenital origin, does not develop until later in life. It will be noted that in some parts of the subcutaneous tissue there are definite lobulated tumours; in others the growths are more diffused. The vessels in the lobulations are sometimes considerably dilated, and intercommunicate freely.

Ellen E-, aged sixteen, was admitted into the Paddington Infirmary on Dec. 17th, 1889. She was then described as a flabby, unhealthy-looking girl, with a dusky complexion, of small stature, and somewhat deficient in telligence. The right calf is now much larger than the left, measuring one inch more in circumference (14 in. and 13 in respectively). The increase in size is due to a diffused mass, which feels like loose adipose tissue, situated at the back of the leg. The veins of the skin covering it are very apparent, and are here and there collected into little subcutaneous purple patches, which are more obvious after the patient has been walking about much. Sinilar masses of loose vascular adipose tissue are to be found on the outer side of the right knee, the back of the right thigh and the right buttock, and the back of the left thigh.

I The case has been brought before the Irarveinn Society.
There are numerous small venous nævi scattered over the shoulders and elsewhere, varying in size from a small pea to a chestnut, and some small, thin, pigmented moles on the trunk. The only part that is free from any of these three forms of abnormality-viz., subcutaneous thickening, venous nævi, and pigment moles-is the left leg. Mr Hutchinson, who has seen the case, has drawn attention to the fact that some of the bones are enlarged-namely, both tibire and possibly the radii. There is a tendency to genu valgum in the right knee, which the patient declares has only developed during the last few months. The patient's intelligence is not very good, but she declares that she never noticed the lumps on her right leg until about a year ago, when she was fifteen years old. However, Dr. Savill considered it probable that these, like the nevi and pioment marks, and possibly even the enlargement of bones, are all congenital defects, coincident in the same in dividual, increasing, as such defects generally do, with age, and only giving rise to inconvenience when sufficiently advanced. As further illustrations of congenital deficiency in this patient, the mental condition may be mentioned and also the "fits" from which she informs us she suffered all her life until a year ago. These "fits" are preceded by a feeling of giddiness, but no nore information can be procured about them. The lumps in her leg prevent her working at the present time on account of the dull, heavy pain she experiences when walking or standing about. The patient is very subject to bronchitis and sore-throat. The viscera are normal, and the skin condition gives rise to no constitutional symptoms. She was in the Lock Hospital for three months just before admission with gonorrhoa. She believes that her father died of bronchitis and dropsy, and her nother in a confinement, but nothing further is known of her hereditary antecedents.

Remarks by Dr. SAVILL. - The disease is by most anthorities believed to be very closely allied to molluscum fibrosum, and a case of the late Dr. John Murray is referred to by Dr. Liveing, ${ }^{2}$ where the two diseases occurred in the same patient. It is wortlyy of note that in that case, as in this, the intelligence was feeble. No special kind of treatment has been adopted besides rest in the recumbent position and the application of an elastic stocking.

WINTON DISTRICT HOSPITAL, QUEENSLAND. THREE CASES OF HEPATIC DISEASE; REMARKS.

(Under the care of Dr. G. C. MAcDonaLd.)

THE cases of hydatid of the liver are examples of a disease very common in the part of the world in which these patients were treated, especially amongst the dwellers in the Bush, who are dependent upon an impure water-supply. So much is this the rule, that Dr. A. Sennett ${ }^{3}$ of Hamilton states that fully one-third of the necropsies which he had made presented evidence of a cyst, which in most instances had undergone spontaneous cure. In Case 2, the enlarged liver, due to the presence of a cyst, simulated the enlargement secondary to cardiac disease. In Case 1 the chief point of interest is the method employed in passing the sutures and securing the cyst to the abdominal wall. Thomas ${ }^{4}$ gives the statistics of abdominal section for hydatid of the liver as about 90 per cent. of recoveries. The third of these cases is illustrative of a very rare affection indeed-a fistulous communication between a bronchus and a bile-duct. Dr. Macdonald thinks that the disease was of syphilitic origin, and the result of the treatment supports his opinion. Ulceration in to the lung secondary to obstruction of a bileduct by a gall-stone is almost unknown. Murchison met with a fatal case in which gall-stones had escaped into the left pleura.

CASE 1. Hydatid cyst; operation; recovery.-Kcoloured servant, aged thirty, was admitted on April 6th, 1890. She complained of a swelling of the abdomen, of loss of flesh, and general weakness. The patient, from whom it was difficult to obtain any distinct history owing to her imperfect knowledge of English, appeared to have noticed the swelling of the abdomen and general weakness for some months, and dated the former condition from the time she received a kick from one of the coloured men. On

2 Handbook on the Diagnosis of Skin Diseases, p. 275. 1 Bit Med Jour, rol ii, 1880 , p 727 . 